\title{
Assessment of Genotoxic Activity of Para-nitrophenol in Higher Plant Using Arbitrarily Primed- polymerase Chain Reaction (AP-PCR)
}

\author{
Mohamed R. Enan \\ Agricultural Genetic Engineering Research Institute, \\ Agricultural Research Center (ARC), Giza, Egypt
}

\begin{abstract}
Paranitrophenol is a common toxic environmental pollutant; the aim of this study was to evaluate the potential of the DNA fingerprinting by AP-PCR assay to detect the DNA damage in the common bean (Phaseolus vulgaris) exposed to different concentrations of paranitrophenol (4.0-720 $\mathrm{nM}$ ). The changes occurring in the fingerprint patterns were likely to be the result of paranitrophenolinduced DNA damage. These changes include variation in band loss and gain. Paranitrophenol was able to induce DNA damage in concentration-related manner with effectiveness at higher concentrations. A total of 488 bands were clearly identified and 39\% markers were polymorphic. Genetic distance between control and exposed plant samples served to produce a dendrogram. The dendrogram comprised three main clusters, one of which including control and plant samples exposed to lower concentrations and the other two clusters included plants exposed to higher concentrations. This study clearly demonstrates that AP-PCR is highly useful for assessing DNA damage in plant exposed to chemicals. To the best of our knowledge, this is the first report of the applicability of paranitrophenol for inducing DNA damage in higher plants.
\end{abstract}

Key words: Genotoxicity, para-nitrophenol, common bean, AP-PCR, DNA damage

\section{INTRODUCTION}

Plants are exposed to various types of environmental xenobiotic, either deliberately as in the case of agricultural pesticides and plant growth regulators or accidentally as compounds present in the polluted air, soil or water. Some genotoxic agents can only injure the integrity of the genome but also affect the expression of DNA directly or indirectly ${ }^{[1]}$. Higher plants provide a useful genetic system for screening and monitoring environmental pollutants ${ }^{[2]}$. They are good indicators of cytogenetic and mutagenic effects ${ }^{[3]}$. The major advantages of plants as monitoring tools are the following: i) they are eukaryotes; ii) they are easy to grow and resistant to environmental stress; iii) they can allow assays of a range of environmental conditions, iv) there is a positive correlation with mammalian cytogenetic assays for mutagenesis, v) plants as animals are able to process complex pollutant molecules ${ }^{[4]}$. Mutagenic activity of chemicals has been analyzed with different plant system as Allium cepa, Arabidopsis thaliana, Hordeum vulgare, Glycine max, Tradescantia spp, Vicia faba and Zea mays. With these systems chromosome aberration assays, mutation assays, search for chlorophyll-deficient mutants and chlorophyll spot mutation, assays for gaseous mutagens, cytogenetic tests and specific locus mutation assays were performed ${ }^{[5]}$. DNA damage is generated by environmental exposure of organism to atmospheric radiation (UV, ionization), heat, desiccation and chemicals. Chemical agents may cause alkylation of bases, interstrand cross links and substitution at reactive carbon or nitrogen atoms within the base structures ${ }^{[6]}$. The use of plant material appears to be particularly practical for the assessment of environmental health risk. Higher plants, sensitive to soil, water and air pollutions, have been used for biomonitoring of DNA damage induced by genotoxic agents ${ }^{[7]}$.

Nitroaromatic compounds have been used in a number of ways, including in medicines, explosives and pesticides. Wide use of these nitro aromatic compounds and their subsequent release leads to environmental pollution. Para-nitro phenol (PNP) is among such compounds found in many different environments. This compound is used on a large scale in the synthesis of the aspirin substitute acetaminophen and in the manufacture of pesticides such as parathion and methyl parathion. In the environment, such pesticides are hydrolyzed and transformed to PNP; these pesticides have been considered to be the main source of PNP that has been detected in the environment ${ }^{[8]}$.

Corresponding Author: Mohamed R. Enan, Ph.D., United Arab Emirates University, College of Science, Biology Department, Al Ain 17551. United Arab Emirates 
Advances in molecular biology have led to the development of a number of selective and sensitive assays for DNA analysis. The random amplified polymorphic DNA (RAPD) ${ }^{[9]}$ and one of the most promising techniques is that of arbitrarily primed PCR (AP-PCR), as semi quantitative method useful for genetic mapping, taxonomy and phylogenetics. The AP-PCR method was successfully applied to detect $\gamma$ ray-induced DNA damage in medaka fish ${ }^{[10,11]}$, genetic alterations in human tumors ${ }^{[12-15]}$ and to evaluate the involvement of a DNA repair gene following genotoxic treatment in Drosophila mealnogaster ${ }^{[16]}$. In the light of the aforementioned information, the objectives of the present study were (a) To detect a possible genotoxic potential of para nitrophenol in common bean (Phaseolus vulgaris, $2 \mathrm{n}=2 \mathrm{x}=22$ ). (b) To investigate whether arbitrarily primed PCR (AP-PCR) could be suitable as rapid methods in assessing genotoxic activity of para-nitrophenol.

\section{MATERIALS AND METHODS}

Chemicals and media: Paranitrophenol (CAS no. 10002-7; 4-hydroxy 1-nitrobenzene; p-nitrophenol) and plant growth medium were purchased from Sigma Chemical Co., St. Louis, MO. USA. Para-nitrophenol was dissolved in water and the sterile stock solution was mixed with MS media ${ }^{[17]}$ at final concentrations $4.0,18,36,72,144,288,360$ and $720 \mathrm{nM}$ )

Plant growth and treatment conditions: Bean seeds were sterilized by immersion in $75 \%$ ethanol for $2 \mathrm{~min}$ followed by $20 \mathrm{~min}$ in $20 \% \mathrm{v} / \mathrm{v}$ sodium hypochlorite, after that seeds were washed five times in sterile distilled water. Thereafter, the seeds were soaked for one hour in distilled water at $25{ }^{\circ} \mathrm{C}$. The seeds were germinated in sterile glass jar with water-saturated cotton at $25^{\circ} \mathrm{C}$ in the growth chamber with a $16 \mathrm{~h}$ day and $8 \mathrm{~h}$ night photoperiod and left to grow until the roots reached 3-5 $\mathrm{mm}$ in length ${ }^{[18]}$. Subsequently, three plant seedlings were transferred to a jar containing MS media supplemented with different concentration of PNP (4.0, 18, 36, 72, 144, 288, 360 and $720 \mathrm{nM})$. Plant seedlings were exposed to PNP for 14 days in the growth chamber under the same previous conditions. After exposure, plants were utilized for chromosomal DNA extraction.

DNA preparation and quantification: DNA extraction was performed using DNeasy plant minikit (Qiagen, USA), following the instruction of the manufacturer. DNA was examined by gel electrophoresis in $1 \%$ agarose in TBE buffer $(1 \times \mathrm{TBE}=$ $90 \mathrm{mM}$ Tris-base, $90.0 \mathrm{mM}$ Boric acid and $2.0 \mathrm{mM}$ EDTA) with ethidium bromide $(0.5 \mu \mathrm{g} \mathrm{mL}-1)$. Electrophoresis of DNA was performed at $100 \mathrm{~V}$ for 35 min and DNA was visualized with a UV Tran illuminator. The concentration of DNA was estimated by comparison to lambda DNA mass marker (Sigama, poole, UK). The quality of DNA was evaluated by reading absorbance at $260 \mathrm{~nm}$ and $280 \mathrm{~nm}$.

AP-PCR assay: A set of 46 decamer primers were preliminary examined for AP-PCR analysis include; 20 primers (Kit-A), 20 primers (Kit-G), in addition, OPD2, OPD7, OPC2, OPE2, OPE16 and OPZ11 designed by the Operon Technologies Inc USA. The PCR was conducted according to Atienzar et al. ${ }^{[19]}$ with some modification related to number of cycles and annealing temperature. DNA amplification was performed with a PCR thermocycler (Genius, techne). HotStarTaq ${ }^{\mathrm{TM}}$ Master Mix kit (Qiagen, Clifton Hill, Vic.) was used for PCR reactions. Before amplification, PCR conditions were optimized for concentrations of primer. For the AP-PCR assay, using $25 \mu \mathrm{l}$ of reaction mixture containing, $10 \quad \mathrm{ng}$ template DNA, $12.5 \mu \mathrm{L}$ HotStarTaq $^{\text {TM }}$ Master Mix ( $1 \times$ PCR buffer, 1.25 units HotStarTaqTM polymerase, $200 \mathrm{mM}$ of each dNTP), 1.5 $\mathrm{mM} \mathrm{MgCl} 2$ and $10 \mathrm{pM}$ primer. The program of thermal cycling was as follows: initial activation step at $95^{\circ} \mathrm{C}$ for $5 \mathrm{~min}$ followed by five cycles of $1 \mathrm{~min}$ at $94^{\circ} \mathrm{C}, 1$ min at $32^{\circ} \mathrm{C}$ and $2 \mathrm{~min}$ at $72^{\circ} \mathrm{C}$ and 40 cycles of $1 \mathrm{~min}$ at $94^{\circ} \mathrm{C}, \quad 1 \mathrm{~min}$ at $36^{\circ} \mathrm{C}$ and $2 \mathrm{~min}$ at $72^{\circ} \mathrm{C}$, with a final extension step at $72^{\circ} \mathrm{C}$ for $5 \mathrm{~min}$. In every experiment a negative control, with all PCR components except DNA template was included to detect contamination.

Electrophoresis of PCR products: After amplification, Electrophoresis of PCR products was performed in $1.8 \%(\mathrm{w} / \mathrm{v})$ agarose (Invitrogen, USA) using a Tris-Borate-EDTA buffer system. Amplified DNA was mixed with $1 / 5$ th volume of gel loading buffer (analytical grade water containing 25\% ficoll, $0.25 \%$ bromophenol blue and $0.25 \%$ xylene cyanol) with $15 \mathrm{ul}$ of this solution loaded onto the agarose gel $^{[20]}$ A DNA molecular size marker [M=100bp DNA ladder, Promega and Invitrogen, UK) was run for each agarose gel. DNA samples were subjected to electrophoresis at $100 \mathrm{~V}$ for $3.5 \mathrm{~h}$, after which, the gels were stained in a $1 \times \mathrm{TBE}$ solution containing ethidium bromide for a period of not less than $40 \mathrm{~min}$. Gels were photographed under UV illumination using a Polaroid camera (CU-5, Eastman Kodak, New York, NY). 
Data collection and statistical analysis: Amplification with each primer was repeated three times and clearly resolvable and reproducible fragments were considered for analysis. Each fragment was treated as a unit character and was scored as 1 (present) or 0 (absent) for the plant samples exposed to different concentrations of paranitrophenol and control (unexposed). To estimate the total genomic damage in each treatment detected by its DNA fingerprint; the number of altered band (loss and gain) in each treatment compared with the control was scored and the sum of changes was divided by total number of amplified bands per each treatment. A dendrogram was constructed by the between-groups linkage method using squared Euclidean distance measurement. The calculations were carried out and graphs were plotted, using the computer statistical program SPSS version 12.0 (SPSS,Chicago, IL, U.S.A.). Genotoxicity judgments were then made on the basis of the distance between the plant samples.

\section{RESULTS}

PCR conditions were optimized using different concentrations of primer from $5 \mathrm{pM}$ to $100 \mathrm{pM}$ (Fig. 1). Optimal conditions were selected based on the reproducibility and scorability of the PCR products. To evaluate the potential of AP-PCR as reliable method for detection of genotoxic effect of parnitrophenol, DNA was isolated from plant samples exposed to different concentrations of PNP and unexposed (control). DNA of these samples was subjected to amplification by APPCR using 46 decamer primers. The results indicated that the primers used could be categorized into four groups: The first group of primers includes twentythree primers out of $46(50 \%)$ did not produce any PCR products. The second group of primers includes eight primers $(17.4 \%)$ these primers are not reproducible (yielded DNA fingerprint with only small number of bands). The third group of primers includes eight primers $(17.4 \%)$ with unique DNA fingerprint (produce polymorphic DNA fingerprint). The fouth group include seven primers $(15.2 \%)$, these primers produced identical DNA fingerprint (monomorphic banding pattern). After a wide test employing 46 arbitrary primers compromising decamer nucleotide of random sequences, 8 primers out of 46 were selected that gave polymorphic DNA fingerprint in term of PCR amplifications. PCR amplifications with each of the selected primers were performed and the reproducible electrophoretic patterns were obtained. Figure 2 shows results obtained for amplification of plant samples exposed to different concentrations of PNP and control.

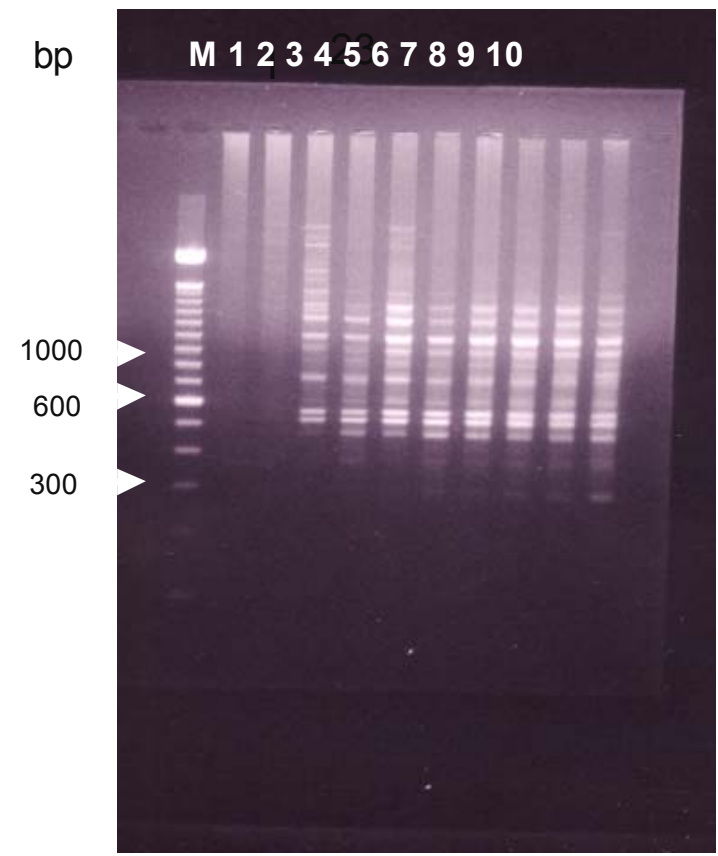

Fig. 1: Optimization of AP-PCR fingerprint. Effect of primer concentration on reproducibility of the reaction. Lane M: 100 bp DNA ladder (Invtrpgen); Lane 1; negative control, Lane 2: 5 pM primer; 3: 10 pM primer; and Lane 4: 15 pM primer. lane 5: $25 \mathrm{pM}$ primer Lane 6: $35 \mathrm{pM}$ primer; lane 7: $40 \mathrm{pM}$ primer; lane 8: $45 \mathrm{pM}$ primer; Lane9: $50 \mathrm{pM}$ primer, lane10: $100 \mathrm{pM}$ primer

Using the selected random primers, 488 bands were produced, 191 bands were polymorphic giving $39 \%$ polymorphism, the bands were in the molecular weights range from 130- $1500 \mathrm{bp}$. Primers OPA18 and OPG2 amplified the minimum and maximum number of bands which were 42 and 81 bands respectively (Table 1).

The quantitative analysis of those bands, expressed as percentage of band loss and gain, shows a concentration-dependant relationship. In case band gain, at the lowest concentration 5 new bands out of 55 bands were amplified represent $9.0 \%$. In the same trend at the highest concentration 11 bands out of 48 were appeared $(22.9 \%)$. The trend of increase in band loss is related to increase in concentration is depicted in Fig. 3a. Similarly, in case band loss, at the lowest concentration; $4.0 \mathrm{nM}$ of PNP 11 bands out of 55 bands were disappeared represent $20 \%$ (Fig. 3a). At the highest concentration, $720 \mathrm{nM}$ of PNP 22 bands out of 48 bands were disappeared represent $45.8 \%$. The genetic similarity index values were calculated by squared Euclidean distance in the AP-PCR amplification profiles of plant samples exposed to PNP and unexposed (control). The genetic similarity index was scored to be 0.241 and 0.562 between the control 


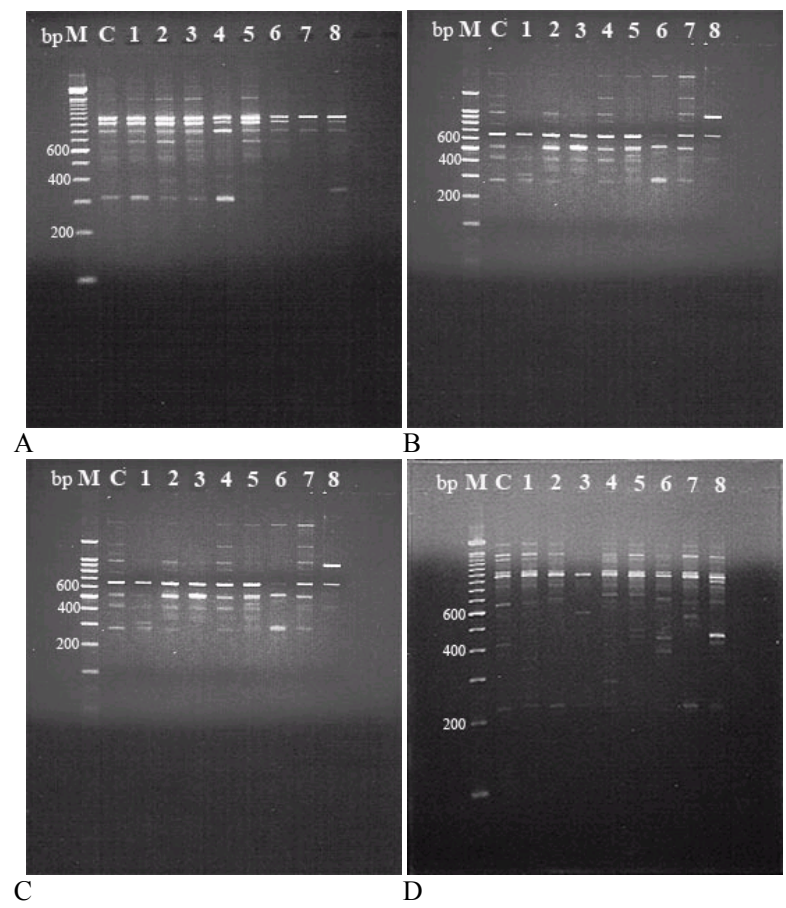

Fig. 2: AP-PCR fingerprints of genomic DNA derived from common bean exposed to the different concentrations of paranitrophenol. AP-PCR reactions were performed using oligonucleotide primers OPA2 (A), OPA20 (B), OPG2 (C) and OPG19(D). Lane C: control; Lanes 1-8: represent plant samples exposed to varying concentration of PNP $(4.0,18,36,72 ; 144 ; 288,360,720 \mathrm{nM}$ respectively)

and plant samples exposed to the lowest concentration, 4.0 $\mathrm{nM}$ and the highest concentration, $720 \mathrm{nM}$, respectively (Table 2). Dendgrogram based on genetic similarity index comprised three main clusters, one of which is large cluster including control and all sample exposed to paranitrophenol at concentrations; 4.0, 18, $36,72,144$ and $360 \mathrm{nM}$, second cluster include only plant sample exposed to $720 \mathrm{nM}$ and plant samples exposed to $288 \mathrm{nM}$ was appeared in separate cluster (Fig. 4).

\section{DISCUSSION}

Although AP-PCR and RAPD are very similar techniques, there is procedural differences between the two techniques, to avoid any confusion, the definition described by Meunier and Grimont ${ }^{[21]}$, has been adopted in this study. After suitable optimization of the PCR conditions the DNA fingerprinting generated by AP-PCR assay performs well in terms of number of bands, product yield and clarity of the profiles. Variation in primer concentration is one of the main sources of RAPD variation ${ }^{[22,23]}$. In this study,
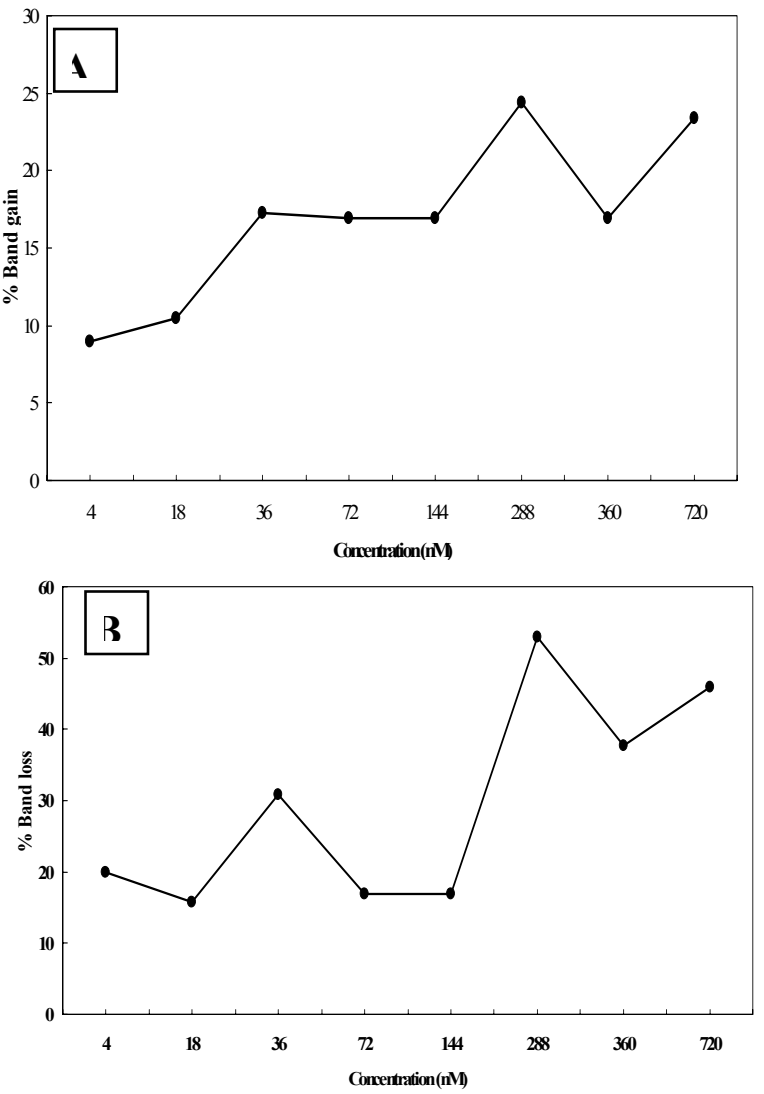

Fig. 3: Genomic damage: The percentage of altered bands in each treatment detected by AP-PCR. A) Average band gains B) average band loss

optimization of cycling conditions to acquire reproducibility fingerprints was carried out by ranging primer concentration from 5-200 pM per reaction. These results indicated that there is a modification in banding patterns when primer concentrations are changed. Smears were noticed with primer concentration lower than $10 \mathrm{pM}$ per reaction. Intense and homogeneous banding was observed between 10$100 \mathrm{pM}$ per reaction. On the other hand, the sensitivity in the detection depended on the sequence of the primer used, the AP-PCR profile that showed the greatest quantitative alteration were those that correspond to the primer of OPG19 and OPA20 (Table1).

Developments in molecular biology suggest new promise for detecting DNA damage; such developments include restriction fragment length polymorphism analysis $^{[24]}$ DNA fingerprinting ${ }^{[25]}$ Recently, a modification of the PCR using only one short random primer (usually 10 nucleotides long) with low stringency was employed to generate DNA fingerprints ${ }^{[26,27,9]}$ such DNA fingerprints have been 


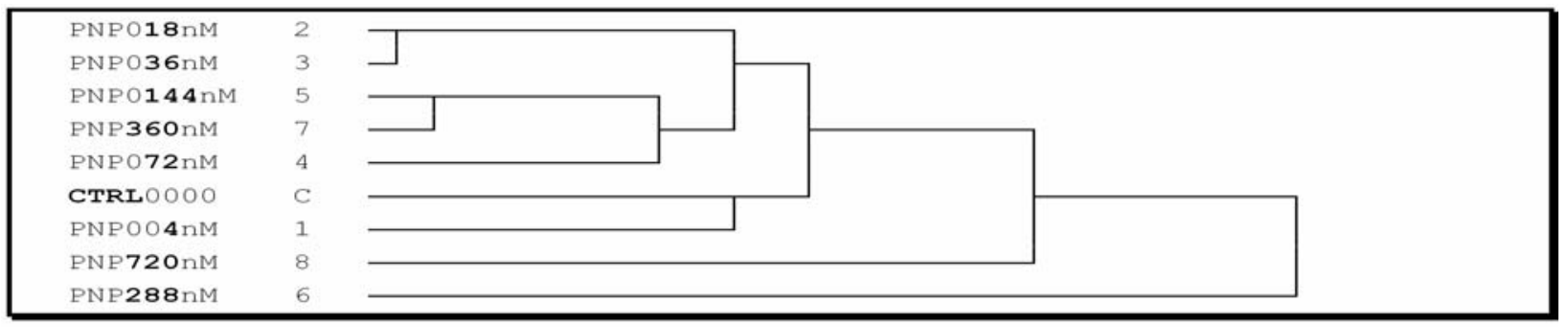

Fig. 4: Dendrogram based on genetic similarity index value calculated from data of eight selected arbitrary primers for plant samples exposed to the different concentration of paranitrophenol and control

Table 1: Sequence of selected random primers, number of total bands and percentage of Polymorphisms calculated from plant samples exposed

\begin{tabular}{lllll}
\multicolumn{2}{c}{ to paranitrophenol and control. } & & & \\
\hline Primers & Sequence (5-3') & $\begin{array}{l}\text { Total number of band } \\
\text { studied }\end{array}$ & $\begin{array}{l}\text { Number of polymorphic } \\
\text { bands }\end{array}$ & Polymorphism (\%) \\
\hline OPG-2 & GGCACTGAGG & 81 & 36 & 44.0 \\
OPG-19 & GTCAGGGCAA & 74 & 39 & 52.0 \\
OPC-2 & GTGAGGCGTC & 58 & 14 & 24.0 \\
OPA-2 & TGCCGAGCTG & 53 & 22 & 29.0 \\
OPA-9 & GGGTAACGCC & 71 & 21 & 12.0 \\
OPA-13 & CAGCACCCAC & 62 & 8 & 35.0 \\
OPA-18 & AGGTGACCGT & 42 & 15 & 76.0 \\
OPA-20 & GTTGCGATCC & 47 & 36 & $39 \%$ \\
\hline Total & & 488 & 191 & \\
\hline
\end{tabular}

Table2: Similarity matrix of plant samples exposed to different concentrations of paranitrophenol and control using Squared Euclidean Distance

\begin{tabular}{|c|c|c|c|c|c|c|c|c|c|}
\hline $\begin{array}{l}\text { Plant } \\
\text { samples }\end{array}$ & Control & $4.0 \mathrm{nM}$ & $18.0 \mathrm{nM}$ & $36.0 \mathrm{nM}$ & $72.0 \mathrm{nM}$ & $144.0 \mathrm{nM}$ & $288.0 \mathrm{nM}$ & $360.0 \mathrm{nM}$ & $720 \mathrm{nM}$ \\
\hline Control & 1.000 & & & & & & & & \\
\hline $4.0 \mathrm{nM}$ & 0.562 & 1.000 & & & & & & & \\
\hline $18.0 \mathrm{nM}$ & 0.603 & 0.613 & 1.000 & & & & & & \\
\hline $36.0 \mathrm{nM}$ & 0.407 & 0.459 & 0.744 & 1.000 & & & & & \\
\hline $72.0 \mathrm{nM}$ & 0.494 & 0.414 & 0.553 & 0.407 & 1.000 & & & & \\
\hline $144.0 \mathrm{nM}$ & 0.494 & 0.463 & 0.652 & 0.504 & 0.595 & 1.000 & & & \\
\hline $288.0 \mathrm{nM}$ & 0.240 & 0.327 & 0.378 & 0.207 & 0.240 & 0.384 & 1.000 & & \\
\hline $360.0 \mathrm{nM}$ & 0.395 & 0.357 & 0.448 & 0.296 & 0.395 & 0.542 & 0.348 & 1.000 & \\
\hline $720 \mathrm{nM}$ & 0.241 & 0.382 & 0.383 & 0.266 & 0.289 & 0.337 & 0.251 & 0.544 & 1.000 \\
\hline
\end{tabular}

used to distinguish between species and between different isolates of the same species. In this study it is proposed that DNA fingerprints obtained using the PCR may be employed to detect DNA damage caused by environmental chemicals such as PNP. In addition, the number of PCR products may be increased if the reaction conditions are less stringent; this may be achieved by reducing the annealing temperature at least for the first few cycles of the PCR. These procedures are referred to as arbitrarily primed PCR (AP-PCR). As a result of these changes in the reaction conditions, a number of PCR products of varying lengths are obtained. The possibility of using DNA fingerprinting by AP-PCR as an alternative biomarker assay was investigated ${ }^{[28-30]}$. It was hypothesized that if an adduct is present in a priming site on the DNA, the primer would be prevented from binding to that site, thus altering the DNA fingerprint; also, DNA fingerprints will be affected by the loss or gain of priming sites due to mutations and by DNA strand breaks.

Similarly, in the present study, DNA damage induced by PNP was reflected by changes in fingerprinting patterns generated by AP-PCR; disappearance of bands and appearance of new PCR products occurred in the profiles generated by exposed plant samples. The disappearance of bands may be 
attributed to the presence of DNA adducts, which can act to block or reduce (bypass event) the polymerization of DNA in the PCR reaction ${ }^{[31,32]}$. In summary, the data suggest that the frequency of DNA adducts increases with increasing concentration of PNP. In earlier studies, DNA alterations (band loss and/or band gain) were detected in $\mathrm{F}_{1}$ progeny descended from the $\boldsymbol{\gamma}_{\text {-irradiated }}$ male medaka fish using the AP-PCR technique ${ }^{[10]}$ and the frequency of band loss was shown to increase with increasing radiation doses ${ }^{[33]}$. In the present study, the results of 4-nitrophenol exposure of plant samples are consistent with these earlier studies. Atienzar et al. ${ }^{[34]}$ concluded that DNA damage and mutations are the main factors that influence RAPD pattern variation between benzo(a)pyrene exposed and non-exposed individuals. In this study, alterations that recurred in the DNA fingerprinting by AP-PCR assay were taken into the account in determination of the DNA damage. The results confirm that PNP acts in concentration dependent, the highest concentration $(720 \mathrm{nM})$, induced genomic alterations in more than a half of the total amplified bands. At the lowest concentrations 4.0, 18.0 and $36.0 \mathrm{nM}$ alteration was still observed but to minor extent. Statistical analysis of the results suggested a significant increase in percentage of band loss was observed at the three higher concentrations of PNP, a similar trend was seen in case band gain (Fig. 3a and b) As general observation the band loss was more frequent than band gain.

Paranitophenol is considered to be not genotoxic or weakly genotoxic although the available toxicological data are incomplete. The AP-PCR clustering revealed that plant samples exposed to the highest concentrations, 288 and $720 \mathrm{nM}$, appeared to be the most distance one from the control. The greatest distance and the smallest distance were observed between control and exposed samples at the highest and the lowest concentration of PNP respectively, the results on the common bean in vitro indicate that paranitrophenol is able to induce DNA damage in a concentration-related manner.

\section{CONCLUSION}

In this investigation the AP- PCR technique has been used to study the genotoxic activity of paranitrophenol. An overall conclusion is that PNP was found to be genotoxic in plant cell and the extent of DNA damage was proportional to the concentration of the paranitrophenol..

\section{ACKNOWLEDGMENTS}

I would like to thank Dr. Franck Atienzar, School of Biological Sciences, Plymouth Environmental Research Centre (PERC), University of Plymouth, UK for his suggestion and constructive idea in this study. I thank Mrs Wafaa Al Dhari from Biology Department, UAE University for her help with photographs.

\section{REFERENCES}

1. Shugart, L. and C. Theodorakis, 1994. Environmental genotoxicity: probing the underlying mechanisms. Environ. Health Perspect., 102: 13-17.

2. Grant, W.F., 1994. The present status of higher plant bioassay for the detection of environmental mutagens. Mutation Res., 310:175-185.

3. Constantin, M.J. and E.T. Owens, 1982. Introduction and perspectives of plant genetic and cytogenetic assays. A report of the US Environmental Protection Agency Gene-Tox Program, Mutation Res., 99: 1-12.

4. Sandermann, H.Jr., 1994. Higher plants metabolism of xenobiotics: the "green liver" concept. Pharmacokinetics, 4: 225-241

5. Conte, C.I. Mutti, P. Puglisi, A. Ferrarini, G. Regina, E. Maestri and N. Marmiroli, 1998. DNA fingerprinting analysis by a PCR based method for monitoring the genotoxic effects of heavy metals pollution. Chemosphere, 37: 2739-2749.

6. Vornarx, E.J., H.L. Mitchell, R. Karthikeyan, I. Chatterjee and B.A. Kunz, 1998. DNA repair in higher plants. Mutat. Res., 400: 187-200.

7. Poli, P.deM.A. de Mello, A. Buschini, V.L.S.S. de Castro, C. Restivo, F.M. Rossiand and T.M.A.D. Zucchi, 2003. Evaluation of the genotoxicity induced by the fungicide fenarimol in mammalian and plant cells by use of the single-cell gel electrophoresis assay. Mutat. Res., 540: 57-66.

8. Kitagawa, W., N. Kimura and Y. Kamagata, 2004. A Novel p-nitrophenol Degradation Gene Cluster from a Gram-Positive Bacterium, Rhodococcus opacus SAO101. J. Bacteriol., 186: 4894-4902.

9. Williams, J.G.K., A.R. Kubelic, K.J. Livak, J.A. Rafalski and S.V. Tingey, 1990. DNA polymorphisms amplified by arbitrary primers are useful as genetic markers. Nucleic Acid Res., 18: 6531-6535.

10. Kubota, Y., A. Shimada and A. Shima, 1995. DNA alterations detected in the progeny of paternally irradiated Japanese medaka fish (Oryzias Latipes). Proc. Natl. Acad. Sci. USA., 92: 330-334. 
11. Shimada, A. and A. Shima, 1998. Combination of genomic DNA fingerprinting into the medaka-specific locus test system for studying environmental germline mutagenesis. Mutation Res., 399: 149-165.

12. Peinado, M.A., S. Malkhosyan, A. Velaquez and M. Perucho, 1992. Isolation and characterization of allelic losses and gains in colorectal tumors by arbitrarily primed polymerase chain reaction. Proc. Natl. Acad. Sci. USA., 89: 10065-10069.

13. Ionov, Y., M.A. Peinado, S. Malkhosyan, D. Shibata and M. Perucho, 1993. Ubiquitous somatic mutations in simple repeated sequences reveal a new mechanism for colonic carcinogenesis. Nature, 363: 558-561.

14. Kohno, T., K. Morishita, H. Takano, D. N. Shapiro and J. Yokota, 1994. Homozygous deletion at chromosome $2 \mathrm{q} 33$ in human small-cell lung carcinoma identified by arbitrarily primed PCR genomic fingerprinting. Oncogene, 9: 103-108.

15. Arribas, R. Capellà, S. Tórtola, L. Masramon, W.E. Grizzle, M. Perucho and M. A. Peinado, 1997. Assessment of genomic damage in colorectal cancer by DNA fingerprinting: prognostic applications. J. Clin. Oncol., 15: 3230-3240.

16. Lopez, A., N. Xamena, O. Cabre, A. Creus, R. Marcos and A. Velazquez, 1999. Analysis of genomic damage in the mutagen-sensitive mus-201 mutant of Drosophila melanogaster by arbitrarily primed PCR (AP-PCR) fingerprinting. Mutation Res., 435: 63-75.

17. Murashige, T. and F. Skoog, 1962. A revised medium for rapid growth and bio assays with tobacco tissue cultures. Physiol. Plant, 15: 473-497.

18. Enan, M. R., 2006. Application of random amplified polymorphic DNA (RAPD) to detect the genotoxic effect of heavy metals. Biotechnol. Appl. Biochem., 43:147-154.

19. Atienzar, F.A., P. Child, A. Evenden, A. Jha, D. Savva, C. Walker and M. Depledge, 1998. Application of the arbitrarily primed polymerase chain reaction for the detection of DNA damage. Mar. Environ. Res., 46: 331-335.

20. Sambrook, J., E.F. Fritsch and T. Maniatis, 1989. Molecular Cloning: A Laboratory Manual. Cold Spring Harbor Laboratory Press, Cold Spring Harbor, New York.

21. Meunier, J.R. and P.A.D. Grimont, 1993. Factors affecting reproducibility of random amplified polymorphic DNA Muralidharan, K. and Wakeland, E.K., fingerprinting. Res. Microbiol. 144: 373-379.

22. Hansen, M., C. Hallden and T. Sall, 1998. Error rates and polymorphism frequencies for three RAPD protocol. Plant Mol. Biol. Rep., 16: 139-146.
23. Virk, P.S., J. Zhu, H.J. Newburry, G.J. Bryan, M.T. Jackson and B.V. Ford-Lloyd, 2000. Effectiveness of different markers for classifying and revealing variation in rice (Oryza sativa) germplasm. Euphytica, 112: 275-284.

24. Botstein, D., R.L. White, M. Skolnick and R.W. Davis, 1980. Construction of a genetic linkage map in man using restriction fragment length polymorphisms. Am. J. Hum. Genet., 32: 314-331.

25. Jeffreys, A. J., 1987. Highly variable minisatellites and DNA fingerprints. Biochem. Soc. Trans., 15: 309-317.

26. Upcroft, P.R. Mitchell and P.F.L. Boreham 1990. DNA fingerprinting of the intestinal parasite Giardia duodenalis. Int. J. Parasitol., 20: 319-323.

27. Welsh, J. and M. McClelland, 1990. Fingerprinting genomes using PCR with arbitrary primers. Nucleic Acids Res., 18: 7213-7218.

28. Castellani, S., N. Mattei, A. Renzoni, C.H. Walker and D. Savva, 1993. Preliminary studies on the use of PCR and DNA fingerprints to detect the genotoxic effects of environmental chemicals. First SETAC World Congress on Ecotoxicology and Environmental Chemistry, Lisbon, Portugal, pp: 246-246.

29. Savva, D., 1996. DNA fingerprinting as a biomarker assay in ecotoxicology. Toxicol. Ecotoxicol. News Rev., 3: 110-114.

30. Walker, C.H., 1994. The Use of Biomarkers to Measure the Interactive Effects of Chemicals. Ecotoxicology and Environmental Safety, 40: 65-70.

31. Donahue, B.A., S. Yin, J.S. Taylor, D. Reines and P.C. Hanawalt, 1994. Transcript cleavage by RNA polymerase II arrested by a cyclobutane pyrimidine dimer in the DNA template. Proc. Natl. Acad. Sci. USA, 91: 8502-8506.

32. Nelson, J.R., C.W. Lawrence and D.C. Hinkle, 1996. Thymine-thymine dimer bypass by yeast DNA polymerase. Science, 272: 1646-1649.

33. Kubota, Y., A. Shimada and A. Shima, 1992. Detection of -ray-induced DNA damage in malformed dominant lethal embryos of the Japanese medaka (Oryzias Latipes) using AP-PCR fingerprinting. Mutation Res., 283: 263-270.

34. Atienzar, F.A., P. Venier, A.N. Jha and M.H Depledge, 2002. Evaluation of the random amplified polymorphic DNA (RAPD) assay for the detection of DNA damage and mutations. Mutation Res., 521: 151-163. 